\title{
Front Matter: Volume 10344
}

, "Front Matter: Volume 10344," Proc. SPIE 10344, Nanophotonic Materials XIV, 1034401 (10 October 2017); doi: 10.1117/12.2286375

SPIE Event: SPIE Nanoscience + Engineering, 2017, San Diego, California, United SPIE. States 


\title{
PROCEEDINGS OF SPIE
}

\section{Nanophotonic Materials XIV}

\author{
Stefano Cabrini \\ Gilles Lérondel \\ Adam M. Schwartzberg \\ Taleb Mokari \\ Editors
}

9-10 August 2017

San Diego, California, United States

Sponsored and Published by

SPIE 
The papers in this volume were part of the technical conference cited on the cover and title page. Papers were selected and subject to review by the editors and conference program committee. Some conference presentations may not be available for publication. Additional papers and presentation recordings may be available online in the SPIE Digital Library at SPIEDigitalLibrary.org.

The papers reflect the work and thoughts of the authors and are published herein as submitted. The publisher is not responsible for the validity of the information or for any outcomes resulting from reliance thereon.

Please use the following format to cite material from these proceedings:

Author(s), "Title of Paper," in Nanophotonic Materials XIV, edited by Stefano Cabrini, Gilles Lérondel, Adam M. Schwartzberg, Taleb Mokari, Proceedings of SPIE Vol. 10344 (SPIE, Bellingham, WA, 2017) Seven-digit Article CID Number.

ISSN: 0277-786X

ISSN: 1996-756X (electronic)

ISBN: 9781510611450

ISBN: 9781510611467 (electronic)

Published by

SPIE

P.O. Box 10, Bellingham, Washington $98227-0010$ USA

Telephone +1 3606763290 (Pacific Time) · Fax +1 3606471445

SPIE.org

Copyright (C) 2017, Society of Photo-Optical Instrumentation Engineers.

Copying of material in this book for internal or personal use, or for the internal or personal use of specific clients, beyond the fair use provisions granted by the U.S. Copyright Law is authorized by SPIE subject to payment of copying fees. The Transactional Reporting Service base fee for this volume is $\$ 18.00$ per article (or portion thereof), which should be paid directly to the Copyright Clearance Center (CCC), 222 Rosewood Drive, Danvers, MA 01923. Payment may also be made electronically through CCC Online at copyright.com. Other copying for republication, resale, advertising or promotion, or any form of systematic or multiple reproduction of any material in this book is prohibited except with permission in writing from the publisher. The CCC fee code is 0277$786 \mathrm{X} / 17 / \$ 18.00$.

Printed in the United States of America.

Publication of record for individual papers is online in the SPIE Digital Library.

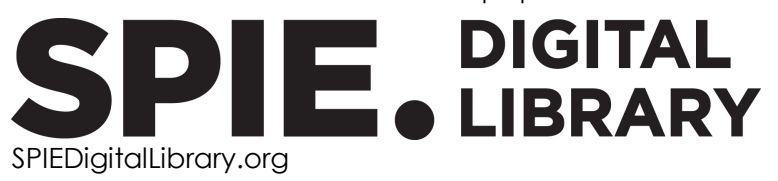

Paper Numbering: Proceedings of SPIE follow an e-First publication model. A unique citation identifier (CID) number is assigned to each article at the time of publication. Utilization of CIDs allows articles to be fully citable as soon as they are published online, and connects the same identifier to all online and print versions of the publication. SPIE uses a seven-digit CID article numbering system structured as follows:

- The first five digits correspond to the SPIE volume number.

- The last two digits indicate publication order within the volume using a Base 36 numbering system employing both numerals and letters. These two-number sets start with $00,01,02,03$, 04, 05, 06, 07, 08, 09, OA, OB ... 0Z, followed by 10-1Z, 20-2Z, etc. The CID Number appears on each page of the manuscript. 


\title{
Contents
}

\author{
$\checkmark$ Authors \\ vii Conference Committee
}

\section{NANOPLASMONIC APPLICATIONS}

1034404 Photocurrent generation from TiN nanostructures by visible light (Invited Paper) [10344-3]

\section{OPTOELECTRONIC PROPERTIES OF NANOMATERIALS}

10344 OE Possibility of cost effective and energy efficient high-quality natural white light sources with new nano-phosphor [10344-14]

10344 OF Quantum-confined and pseudo Stark effects in the semiconductor conical quantum dot [10344-15]

\section{SYNTHESIS AND CHARACTERIZATION OF NANOPHOTONIC MATERIALS I}

10344 OG Optical transmissivity of metallic nanowires [10344-18]

10344 Ol Controlling the magic and normal sizes of white CdSe quantum dots [10344-20]

10344 OK All-dielectric cylindrical nanoantennas in the visible range [10344-22]

$10344 \mathrm{OL}$ Third order optical nonlinearity investigation of germanium quantum dots embedded in silica matrix [10344-35]

\section{SYNTHESIS AND CHARACTERIZATION OF NANOPHOTONIC MATERIALS II}

10344 ON Nanostructured organosilicon luminophores for efficient and fast elementary particles photodetectors [10344-25]

1034400 Structural and optical characterization of highly anisotropic low loss Al:ZnO/ZnO multilayered metamaterial with hyperbolic dispersion grown by pulsed layer deposition (Invited Paper) [10344-26]

POSTER SESSION

$10344 \mathrm{OQ}$ Phase analysis of $\mathrm{VO}_{2}$ thin film and the mechanism of the electrically triggered metalinsulator transition of $\mathrm{VO}_{2}$ [10344-29] 
10344 OR Luminescence and transient lifetime studies for energy transfer of PbS QD films [10344-30]

10344 OT Optical properties of cyanine dyes in nanotubes of chrysotile asbestos [10344-32]

10344 OU Biocompatible Er, Yb co-doped fluoroapatite upconversion nanoparticles for imaging applications [10344-33] 


\section{Authors}

Numbers in the index correspond to the last two digits of the seven-digit citation identifier (CID) article numbering system used in Proceedings of SPIE. The first five digits reflect the volume number. Base 36 numbering is employed for the last two digits and indicates the order of articles within the volume. Numbers start with 00, 01, 02, 03, 04, 05, 06, 07, 08, 09, OA, OB...0Z, followed by 10-1Z, 20-2Z, etc.

Belotitskii, Vladimir I., OT

Bishel, David, OL

Borshchev, Oleg $\vee .$, ON

Brown, Gail J., OR

Cheung, William, OL

Choi, Jeongyong, $0 Q$

Chung, Shu-Ru, Ol

Dalal, Reena, OK

Das, Anirban, OR

Dass, Chandriker K., OR

De, Dilip K., OE

Dvoyan, K. G., OF

Gao, Fei, OL

Hendrickson, Joshua R., OR

Iorkyaa, Ahemen, OE

Ishii, Satoshi, 04

K. M., Kurias, OU

Kalra, Yogita, OK

Kelly, Priscilla, 00

Kim, Bong-Jun, $O Q$

Kim, Seong Hyun, $0 Q$

Kleymyuk, Elena A., ON

Kumar, Ajeet, OK

Kumzerov, Yuri A., OT

Kuznetsova, Lyuba, 00

Lee, Yong Wook, $0 Q$

Lim, Sang Chul, $O Q$

Liu, Mingzhao, 00

M. K., Jayaraj, OU

Mini, Joseph, OL

Montes, Salvador, OL

Nagao, Tadaaki, 04

Nairat, Mazen S., OG

Olukunle, Olawole C., OE

Ponomarenko, Sergey A., ON

R., Anjana, OU

Salamo, G. J., OF

Seo, Giwan, $0 Q$

Shankhwar, Nishant, OK

Shinde, Satish L., 04

Sinha, R. K., OK

Skorotetcky, Maxim S., ON

Starikova, Tatyana Yu., ON

Starovoytov, Anton A., OT

Su, Yu-Sheng, Ol

Surin, Nikolay M., ON

Sysoeva, Anna A., OT

Tereshenko, Alexey S., ON

Tshantshapanyan, A. A., OF
Ullich, Bruno, OR

Vartanyan, Tigran A., OT

Vlahovic, B., OF

Wai, Chien M., OR

Wang, Joanna S., OR

Willoughby, Alexander, OE

Zhang, Liangmin, $\mathrm{OL}$

Zhang, Wenrui, 00 
Proc. of SPIE Vol. 10344 1034401-6

Downloaded From: https://www.spiedigitallibrary.org/conference-proceedings-of-spie on 26 Apr 2023 Terms of Use: https://www.spiedigitallibrary.org/terms-of-use 


\section{Conference Committee}

Symposium Chairs

Harry A. Atwater Jr., California Institute of Technology (United States)

Nikolay I. Zheludev, Optoelectronics Research Centre

(United Kingdom) and Nanyang Technological University

(Singapore)

Symposium Co-chairs

James G. Grote, Air Force Research Laboratory (United States)

David L. Andrews, University of East Anglia (United Kingdom)

Conference Chairs

Stefano Cabrini, Lawrence Berkeley National Laboratory (United States)

Gilles Lérondel, University de Technologie Troyes (France)

Adam M. Schwartzberg, Lawrence Berkeley National Laboratory (United States)

Taleb Mokari, Ben-Gurion University of the Negev (Israel)

Conference Program Committee

David L. Andrews, University of East Anglia (United Kingdom)

Angus J. Bain, University College London (United Kingdom)

Mireille H. Blanchard-Desce, Université de Rennes 1 (France)

Robert W. Boyd, University of Rochester (United States)

Zeno Gaburro, Universita degli Studi di Trento (Italy)

Aaron W. Harper, The University of Southern California (United States)

Ghassan E. Jabbour, Arizona State University (United States)

François Kajzar, University Politehnica of Bucharest (Romania)

Dmitri I. Kovalev, University of Bath (United Kingdom)

Paras N. Prasad, University at Buffalo (United States)

Dmitri Talapin, The University of Chicago (United States)

Younan Xia, Georgia Institute of Technology (United States)

\section{Session Chairs}

1 Nanoplasmonic Applications

Taleb Mokari, Ben-Gurion University of the Negev (Israel) 
2 Novel Plasmonic Materials

Erika Penzo, Lawrence Berkeley National Laboratory (United States)

3 Photonics

Adam M. Schwartzberg, Lawrence Berkeley National Laboratory (United States)

4 Optoelectronic Properties of Nanomaterials

Adam M. Schwartzberg, Lawrence Berkeley National Laboratory (United States)

5 Synthesis and Characterization of Nanophotonic Materials I Gilles Lérondel, Université de Technologie de Troyes (France)

6 Synthesis and Characterization of Nanophotonic Materials II Ajay Singh, Los Alamos National Laboratory (United States) 